\title{
Teacher Evaluation on Students' Knowledge of Writing and the Texts Produced
}

\author{
I Made Sutama $^{1 *}$, I Nengah Suandi ${ }^{1}$ \\ ${ }^{1}$ Universitas Pendidikan Ganesha, Indonesia \\ *Corresponding author. Email: made.sutama@undiksha.ac.id
}

\begin{abstract}
Evaluation of learning to write is very crucial to do. Therefore, we need a model to do it. This study aims to find (1) how teachers assess the mastery of knowledge aspects in learning to write, and (2) how teachers assess students' written products. For achieving this goal, a qualitative design is applied. The subjects of this study were Indonesian language teachers at SMPN 1 Singaraja. Research data obtained from the syllabus and implementation plan of learning Indonesian using the documentation method and were analyzed qualitatively. The research results showed that (1) the mastery of the knowledge aspect in learning to write was mostly evaluated by a written test, and (2) the students' writing products were evaluated using a scoring rubric developed by the teacher. The profile contained written components that need to score. Each component has several indicators. The score is determined per indicator. Thus, if the rubric is applied, the scores for all components will be obtained.
\end{abstract}

Keywords: Evaluation, Knowledge of Writing, Texts

\section{INTRODUCTION}

Evaluation is an essential part of learning at all levels of education. All learning activities carried out must always be followed or accompanied by assessment activities.[1] The European University Association, for example, states, "The evaluation of learning and teaching has long been an important institutional activity due to the emphasis placed on quality assurance in the European Higher Education Area."[2] Even in the curriculum study, evaluation is stated as one of the main components other than objectives, learning, and media.

There are several reasons why evaluation has a vital position in learning.[1] Through evaluation, learning outcomes could be measured. Evaluation can also be used to determine the quality of learning. Furthermore, the results of the evaluation can be used as feedback for subsequent learning activities. Finally, if the evaluation is carried out following the existing guidelines, an increase in learning quality can be guaranteed.

The same thing happens to all subject matters, including learning Indonesian with all aspects of language skills being developed, one of which is learning to write. As one of the components of Indonesian language learning, the quality of learning to write also needs to be improved. Therefore, evaluation of learning to write is also necessary. White (in Crusana, Plakan, and Gebril stated, "Assessment remains aubiquitous element of any writing classroom and is vitally important to the academic growth of students."[3]

Learning evaluation is not something that stands alone. Evaluation is the end or follow-up of the previous process. To be able to do an evaluation, data in the form of a scoresare needed. Meanwhile, to get scores, measurements are needed. It means that evaluation needs to be preceded by measurement. The measurement itself requires a tool that is suitable for the measurement purpose. Therefore, before measurements are made, a device called a test is needed.

In language learning, evaluation changes along with the approach adopted by the applied curriculum and its learning objectives. Currently, when the 2013 Curriculum is implemented, the approach adopted is a text-based approach. The learning objective is that students have mastery of text theory, which includes the structure and characteristics of the text's language, and are skilled at producing text, both oral and written. Therefore, in the measurement process, the point being tested is the mastery of text theory and the skills to produce texts, both oral and written.

Then, what about the evaluation of learning to write as a language skill? As stated earlier, evaluation of learning to write should refer to mastery of the specified competencies. In general, there are two defined competencies, namely core competencies relating to 
knowledge of written texts, which include the structure and characteristics of written text (KI 3), and core competencies relating to skills in producing written texts (KI 4). More specifically, the KI will be downgraded into KDs according to the type of text being studied.

The problem is that many teachers are not yet skilled at conducting evaluations and preceding activities, such as how to measure and score student performance, both on mastery of knowledge about written texts and mastery of skills in producing written texts. Mellati and Khademi stated, "Research in many countries has demonstrated that many teachers are inadequately trained and illprepared to develop, administer and interpret the results of different types of assessment. In other words, the literature has revealed that teachers have difficulties in test development, administration, and interpretation."[4]

Cognitively, writing is a process. As a process, writing requires stages to explore ideas, organize ideas, write an initial draft, revise, and produce a final draft. To revise the first draft, students need teacher involvement in responding to the initial draft produced by students. The teacher's response is needed by the students as a basis for making revisions. To give a good response, which leads students to make improvements to the initial draft, specific skills from the teacheris highly required.

Therefore, a model for how the evaluation and all the preceding processes are carried out is needed. This model will only be obtained through research. Since the research carried out is to obtain a model, it is necessary to collaborate with a superior school as the setting for the research with experienced teachers. In that context, a research was conducted on "Evaluation of Text-Based Writing Learning at State Yunior High School (SMPN) 1 Singaraja." At the school, it is expected to find out how the evaluation of learning to write is carried out.

Based on the explanation in the background section, the following research problems were formulated.

1. How do teachers evaluate students' mastery of knowledge aspects of writing?

2. How do the teachers score the final drafts of the writing produced by the students?

As the base of the research, the following theories are used. Learning to write is a part of learning Indonesian. According to the 2013 Curriculum (K-13), Indonesian language learning adopts a scientific approach and a textbased approach. The scientific approach is adopted because it becomes the foundation for all subjects matter under the K-13 umbrella. The text-based approach is adopted exclusively by language subjects matter. The purpose of learning Indonesian, according to $\mathrm{K}-13$, is to develop the language and literary competences of students through listening, reading, and writing activities (Suherli et al., 2016: iii).[5] It is further stated that to achieve this goal, what is taught is not only the mastery of language but also language skills, both oral and written one.
In order to support Indonesian language learning with such goals and adopt the approach adopted, three methods are suggested to be used in managing to learn.[6] The first is discovery learning, the second is problem-based learning, and the third is project-based learning.

Meanwhile, the material to support learning, under the approach adopted, is text, both at the level of knowledge and skills to produce it.[7] Texts contain wellarranged words to communicate meaning (Anderson, 1997 in Priyatni, 2014: 65).[6] At junior high school level, there are 21 types of texts with different characteristics that students from grade VII to class IX must master, both in terms of function, structure, and language rules.[7]

Along with the stated objectives and learning materials, the evaluation is adjusted accordingly. Evaluation is related to students'skills in producing text and students' mastery of the text and linguistic characteristics.

There are several stages in producing text.[8] The first is understanding the writing assignment given; the second is brainstorming individually or in groups; the third is organizing the ideas that arise from the process; the fourth is writing an initial draft with the raw material of ideas that have been organized. The fifth is revising and editing the initial draft of the resulted text. The last task is writing the final draft. In the context of learning to write, writing revisions and edits can be done based on the responses given by the teacher.

To support learning to write as a process, teachers need to respond to students' initial drafts. "The purpose of giving feedback to students is to alter and improve students' learning while instruction is taking place. To provide such feedback, teachers must continuously assess student learning and behavior".[9] Therefore, Hayland states that giving feedback is considered the most important task of teachers in learning to write. It corresponds to the needs of students as writers. [10] It is in line with what Bowden explained. Bowden stated, "Most students in this study read instructors' comments and took them seriously. They seemed to appreciate the comments; they tried to understand them; and they worked to figure out what, if anything, to do in response. "Such formative feedback aims to encourage the development of students' writing and is seen as essential in enhancing and consolidating learning activities. It is natural, then, if the feedback given to the students' initial drafts make their final drafts better.[11]

According to Hayland, the nature of responses can vary widely, and the practice of giving feedback can differ depending on the teacher's tendency as well as the type of task given and the effect it wants to have.[10] However, in general, teacher feedback can be divided into two, namely: conferences and written comments.[12] There are many techniques offered to teachers for responding to student writing. These techniques are (1) giving written comments on student 
work, (2) using rubrics to score students' writing, (3) minimal marking in the text produced by students, (4) giving recorded oral comments, and (5) use computeraided software.

After students make revisions and edit the initial draft of their writing, they write a final draft. This final draft should be scored by the teacher as a basis for evaluating. Sutama, based on various sources, stated that there are three ways teachers can choose to score students' writing.[13] The first way is impressive scoring. In this way, the teacher only gives a single score to the students' writing based on the impressions they perceive. The second way is the primary trait scoring. This method allows the teacher to set the focus of scoring on student writing. For example, the teacher focused the scoring on organizational aspects only and, at other times, focused scoring on aspects of language only. This method lightens the teacher's burden, but the scores obtained do not reflect the quality of the writing as a whole. The third way is analytic scoring. This scoring views writing as consisting of several components. Each component can be considered to have a different urgency in building the text's quality to give a different weight. Each component is scored based on an assessment profile, and the final score of the paper is the total score of all components.

There are several similar studies related to this research; the first is Normah binti Othman research.[9] This research was conducted in a school in Malaysia. His research is entitled "The Primary Trait Scoring Method for Classroom-Based Assessment for Students" Direct Writing. "In this study, it was examined how the teacher gave a score focused on certain components of writing produced by students. His article was published in the International Journal of Learning \& Development, Vol. 14, No. 3: 51-61. The second is research by Yinghui and Dan.[12] This research took place at a college in Hong Kong. His research is entitled "A Comparative Study of Teacher Feedback and Automated Essay Scoring in College English Writing." In this study, the effects of giving feedback by the teacher and software-based scoring on student writing were investigated. His article appears in the International Journal of Linguistics and Communication, Vol. 3, No. 2: 82-97. Compared to these two studies, the current research differs both in the research background and focus.

\section{METHODS}

\subsection{Research Design}

Based on the formulations of the problems to be investigated, this study used a qualitative design. The design was used to answer the research problems, in which the data needed was not data in terms of numbers. The required data is in the form of verbal data.

\subsection{Setting and Participants}

The subjects of this study were all teachers who teach Indonesian at SMPN 1 Singaraja. In total, there are seven of them distributed to teach at three levels, namely: class VII, class VIII, and class IX. Meanwhile, this research aims to evaluate learning to write with all the stages that precede it in the context of text-based learning.

\subsection{Data Collection Method(s) and Analysis}

In line with the research problems, the data were: first, related to how teachers evaluate students' mastery of aspects of knowledge about writing, and second, how teachers score the final drafts of students' writing. Based on the required data, two main methods were used to collect it: the documentation method and the interview method. The documentation method is used to obtain data from documents in the form of syllabus and lesson plans for the 2019/2020 academic year made by the teacher in which there is a test used to assess student knowledge about writing and a scoring model applied by the teacher to the students' final drafts. The interview method is used for enriching data collected by the documentation method.

The collected data will be analyzed qualitatively, with the stages of data reduction, data classification, data presentation, and conclusions formulation. The results of the data analysis are presented narratively.

\section{FINDINGS AND DISCUSSION}

There twenty-one text materials provided to achieve the defined core competencies and basic competencies. The materials were distributed into three grade levels: seven in grade VII, eight in grade VIII, and six in grade IX. The materials in grade VII included descriptive, fantasy stories, procedures, observation reports, folk poetry, folk tales, and letter text. The materials in class VIII included news, advertisements, expositions, poetry, explanations, reviews, persuasion, and drama text. The materials in grade IX included reports, speeches, short stories, responses, discussions, and inspirational story texts.

\subsection{How Teachers Evaluate Students' Mastery of Knowledge Aspects of Writing}

Referring to the syllabus and the lesson plans used, the following was the teachers' method to evaluate students' mastery of aspects of knowledge about writing. The presentation wasstarted in grade VII. For descriptive text learning, the teacher asked the students to identify a descriptive text's contents and features, both concerning the structure and linguistic rules, and then reported it in written form. Besides, the students were also asked to show the errors in the descriptive text they were having. When studying fantasy story texts, students were asked to identify the general features, the communication objectives, and the structure of the fantasy story text. 
They were given a written test to identify the structure of the fantasy story; to determine the pattern of fantasy story development, and improved word, sentence, and spelling choices. To evaluate the students' mastery of knowledge related to the procedural text, the teacher chose an assignment technique and a written test. The students were asked to identify the general features, communication objectives, and procedural text structure through assignments. Students were evaluated with the written test concerningtheir mastery of the procedural text's structure and pattern, choice of words, sentences, and spelling in the procedural text. When studying the observation report (OR) text, students' knowledge was evaluated by giving assignments and written tests. Through assignments, the students were asked to determine the general characteristics and identify the OR text structure. A written test was then used to measure the students' mastery of the pattern of OR text development and the choice of words, sentences, and spelling in the procedural text. For personal letter material, the teacher evaluated the knowledge in two ways, namely: assignments and written tests. Through assignments, the students were asked to determine the official letters' elements and systematics that were being read. Students were asked to improve the choice of words, sentences, and spelling in the text through a written test. When students were invited to learn about folk poetry, in terms of knowledge, students were evaluated regarding their mastery of the general characteristics and communication objectives of folk poetry through assignments. Besides, through a written test, students were tested regarding the pattern of folk poetry development. For folklore material (fable/legend), students were evaluated through assignments concerning their mastery of the general characteristics and communication objectives of the fable/legend story. Meanwhile, utilizing a written test, students' mastery was evaluated about variations in orientation, complications, resolution, and codes in folklore.

In class VIII, the following was what the teacher did in evaluating students' mastery of knowledge aspects of writing. For news texts, through written tests, students were asked to determine the news text elements, identify the main points of the news text, and identify the news text's structure and language rules. When students were assigned to study advertising text material, slogans, or posters, they were evaluated on the aspects of knowledge; they were evaluated regarding the elements of advertising text, slogans, or posters and their characteristics through written tests. For the exposition text material, the students' mastery of the text's knowledge aspect was evaluated concerning the exposition text elements through a written identification test. Besides, they were also evaluated regarding their mastery of language principles through the same type of test. When students were learn poetry text material, their mastery of knowledge about poetry was evaluated by written tests. Its scope was to identify the content, elements, and types of poetry text. Besides, his mastery of writing techniques was also evaluated. To evaluate explanatory text aspects, the students were given a written test that required them to identify the explanatory text's characteristics and patterns/structures and showed ideas in the explanatory text. Through written tests, students were also required to identify the rules of explanatory text. When the students studied the review text material, their mastery of the text sections, their strengths and weaknesses, and the review text's structure and language were evaluated. When students learned persuasion texts, aspects of knowledge were evaluated in writing. Their mastery related to the types of suggestions, invitations, directions, and considerations of the persuasion text's content and the structure and language elements of the persuasion text was evaluated. When grade VIII students learned the final material, namely drama texts, their mastery of knowledge related to drama texts was also evaluated in writing or written tests. The knowledge referred to was the knowledge of drama text elements, drama text characteristics, and drama text rules.

The following was how teachers evaluated the aspects of knowledge in learning to write in class IX. When studentsstudied the report text material, aspects of knowledge were evaluated by written tests. The mastery of the material being evaluated was the content of the experiment report information, the experiment report text structure, and the experimental report text's language characteristics. When students studied speech text material, the knowledge aspects that were evaluated were the ideas, thoughts, views, directions, or messages in the speech, the structure, and language characteristics of the persuasive speech text. The way to evaluate it was to use a written test. The following material was short story text. When students studied this material, the evaluation was carried out by written tests as well. The test materials included short story building elements, short story structure, and short story language characteristics. When students were assigned to study response text material, their mastery of knowledge aspects, which included identifying critical response text content, structure, and language characteristics, was also evaluated by a written test. The written test was also used when students were invited to learn about discussion text material. The test's scope was to identify the content of the discussion text, the structure, and the discussion text's language. The last material given in grade IX was an inspirational story text. To evaluate the mastery of the knowledge aspect of this material, a written test was used. The test was used to measure students' mastery of the contents of the inspirational story text, structure, and language characteristics of the inspirational text.

If we look at how the teacher evaluated students' mastery of the aspects of knowledge in learning to write, the dominant thing was written tests. There were several possible causes for this trend. The written test is more likely to take a thorough measurement. With a written test, all students answer all test items simultaneously with the same duration of time. It isdifferent if students are given an oral test. They have to be asked questions and answer them, in turn, to not answer all questions due to 
time constraints. Correspondingly, the written test is fairer. All students get the same questions in the same number. If a rotating oral test is carried out, there is a coincidence factor. Individual students may happen to get easy questions, while other students will happen to get challenging questions. Another possibility is that the written test is more comfortable to administer. All students can be given the test at the same time. Besides, scoring is also more comfortable because it does not have to be done directly during the test.

\subsection{How Teachers Score the Final Writing Draft Produced by Students}

After the students wrote the final draft, the teacher did the scoring. Scoring was done by referring to the scoring rubric that was previously developed and inserted in the lesson plan, which was used as a learning guide. The rubric contained written components that needed to be scored. Each component had an indicator, and a score was given based on the indicators that the component could fulfill. Thus, if the rubric was followed, scores for all components would be obtained. The total score of the writing was the sum of the scores of all components.

The example is when grade VII students were assigned to learn descriptive texts. To score a final draft of a student's writing, the teacher used a scoring rubric. The rubric used consisted of five components, namely: (1) title, (2) identification, (3) description, (4) closing, and (5) language use. In the title component, there were four indicators, namely: (a) expressing particular objects, (b) not in the form of sentences, (c) using capital / lowercase letters appropriately, and (d) without being given a period. In the identification component, there were four indicators, namely: (a) there was an introduction to the object described, (b) there was general information about the object, (c) there were no sentence structure errors, and (d) there were no punctuation errors. In the description component, there were four indicators, namely: (a) there was a detailed explanation of the physical object, (b) there were no errors in sentence structure, (c) the choice of words was fresh and varied, and (d) there were no punctuation errors. In the closing component, there were four indicators, namely: (a) there was a summary of responses to the object, (b) there was an impression of what was being described, (c) there were no errors in sentence structure, and (d) the choice of words was fresh and varied. In the language use component, there were four indicators, namely: (a) there were details of concrete language, the figure of speech to describe as if the reader saw something, (b) there were details of concrete language, the figure of speech to describe as if the reader heard something, (c) there were details concrete language, the figure of speech to describe as if the reader felt something, and (d) there were details with concrete words.

If the teacher scores the final draft of the students' writing, it appears that the teacher chooses analytic scoring with self-developed rubrics. It appears to be due to the teacher knowing scoring and rubric development.
It is in line with what was stated by the CCCC Committee on Assessment. "The methods and criteria that readers use to assess writing should be locally developed, deriving from the particular context and purposes for the writing being assessed."[14] There are three types of scoring: impressive, analytic, and primary trait. Compared to another scoring, namely the expressive scoring and the primary trait scoring, analytical scoring is more representative in describing the quality of student writing and is more valid and ensuring the scoring's reliability. It is in line with Moxley's research entitled Big Data, Learning Analytics, and Social Assessment1.[15] In that research, he states, "Findings suggest the use of the rubric across genres, sections, and courses facilitates a high level of inter-rater reliability among instructors." In analytic scoring, a scoring rubric used contains all the components of writing that need attention. In impressive scoring, the teacher only relies on the general impression of the students' writing as the basis for scoring. In focused scoring, only one writing component is chosen by the teacher to be noticed and scored.

\section{CONCLUSIONS}

Based on the explanation of the results and discussion part, two things can be concluded. First, the teacher measures the students' mastery of knowledge aspects in writing by tending to use written tests. Second, the teacher scores the final draft of the students' writing using a self-developed rubric. The rubric contains the concerned writing components and indicators as a basis for scoring.

\section{AUTHORS' CONTRIBUTIONS}

I Made Sutama and I Nengah Suandi developed the research proposal, did the research, disscused the results, and contributed to the final manuscript.

\section{ACKNOWLEDGMENTS}

This research was supported by Ganesha University of Education.

\section{REFERENCES}

[1] B. Nurgiyantoro, Penilaian Pembelajaran Bahasa Indonesia Berbasis Kompetensi, BPFE, 2010.

[2] C. Dewhirst and A. Gover, Evaluation of Learning and Teaching (Thematic Peer Group Report), European University Association, 2019. DOI: https://www.eua.eu/component/publications/public ations.html?id=813:evaluation-of-learning-andteaching-thematic-peer-group-report

[3] D. Crusana, L. Plakans, and A. Gebril, Writing Assessment Literacy: Surveying Second Language Teachers' Knowledge, Beliefs, and Practices, 
Assessing Writing, 28, 2016. htpps://daneshyari.com/en/article/344214

[4] K. Mellati and M. Kademi, Exploring Teachers' Assessment Literacy: Impact on Learners' Writing Achievements and Implications for Teacher Development, Australian Journal of Teacher Education, Volume 43, Issue 6, Article 1, 2018. DOI: https://file.eric.ed.gov

[5] Suherli et. al., Bahasa Indonesia, Kementerian Pendidikan dan Kebudayaan Republik Indonesia.

[6] E. T. Priyatni, Desain Pembelajaran Bahasa Indonesia dalam Kurikulum 2013, Bumi Aksara, 2014.

[7] E. Kosasih and E. Kurniawan, Jenis-jenis Teks, Fungsi, Struktur, dan Kaidah Kebahasaan (Mata Pelajaran Bahasa Indonesia SMP/MTs), Penerbit Yrama Widya, 2019.

[8] C. A. Boardman, Writing to Communicate: Paragraphs, Pearson Longman, 2008.

[9] Normah binti Othman, The Primary Trait Scoring Method for Classroom-Based Assessment for Students' Direct Writing, International Journal of Learning \& Development, Vol. 14, No. 3, 2014, pp. 51-61. DOI: https://pdfs.semanticsschoolar.org

[10] K. Hyland, Second Language Writing, Cambridge University Press, 2005.

[11] D. Bowden, Comments on Student Paper: Student Perspectives, The Journal of Writing Assessment, Volume 11, Issue 1, 2018. DOI: http://journalofwritingassessment.org/article.php?a rticle $=121$

[12] H. Yinghui and Z. Dan, A Comparative Study of Teacher Feedback and Automated Essay Scoring in College English Writing, International Journal of Linguistics and Communication, V, 2015. DOI: http://ijlcnet.com

[13] I. M. Sutama, Pembelajaran Menulis, Pustaka Pelajar, 2016.

[14] CCCC Committee on Assessment, Writing Assessment: A Position Statement, NCTE, 2014. DOI: https://ncte.org/statement/writingassessment/

[15] J. Moxley, Big Data, Learning Analytics, and Social Assessment, The Journal of Writing Assessment, Volume 6, Issue 1, 2013. DOI: http://www.journalofwritingassessment.org /article.php?article $=68$ 